\title{
Conclusion: Beyond Liberal
}

\section{Internationalism}

\author{
A N A A T I C, J OHA N A C O N T E R I O
}

A N D D O R VARGHA

The contributors to this special issue have taken up the challenge of reconsidering some of the fundamental assumptions that have traditionally underpinned the history of internationalism. In doing so their articles (some more explicitly than others) have addressed two central questions: who were the internationalists and where was internationalism taking place? The answers to these questions seem deceptively simple. However, as the articles in this issue have demonstrated, agents of internationalism are as diverse in age, gender and social status as the fields in which they operate.

\section{Scales}

The history of internationalism parted ways some time ago with international history', which focused on diplomatic relations among nations. With the rise of the global as a frame of analysis, research moved beyond diplomatic history of nationstates to social and cultural histories of empires, post-colonial settings and global networks. Historians increasingly began to investigate the movements of people, goods, ideas and practices across national boundaries and continents. ${ }^{1}$ Still, diplomatic and political histories have retained their appeal, through their exploration of how international organisations operate and interact with each other and how ideas of internationalism have formed among the leadership of international organisations. This scholarship has moved the field away from hagiographical accounts of the great men of internationalism, laying out organisational structures and mapping out high politics, changing ideas and the tensions between theories and practice of internationalism. ${ }^{2}$

Department of History, Classics and Archaeology, Birkbeck College, 26 Russell Square, London WCiB 5DQ; Emails : a.antic@bbk.ac.uk; j.conterio@bbk.ac.uk; d.vargha@bbk.ac.uk

1 Peter Mandler, 'The New Internationalism', History Today, 62, 3 (20I2).

2 Iris Borowy, Coming to Terms with World Health: The League of Nations Health Organisation 19211946 (Frankfurt am Main: Peter Lang, 2009); Paul Weindling, International Health Organisations and 
More recently, research on international organisations has interrogated the border between 'technical' and 'political' issues and has contested linear and teleological narratives of interwar internationalism. By challenging the idea of organisations as monolithic structures, this work has examined the personnel working in and alongside them and explored the cultural, political, intellectual and social context within which they operated. ${ }^{3}$ Other scholars have offered path-breaking work that has shifted the geographic focus of analysis and integrated imperial and post-colonial or socialist histories into the field. ${ }^{4}$

Building on this scholarship, the essays in this volume have contributed to the history of internationalism by moving away from the bureaucratic centres of international organisations and have aimed instead to understand internationalism from local perspectives that usually fall outside of the purview of analysis. They have turned their attention away from the usual suspects of diplomats, high officials of international organisations and intellectuals of liberal internationalism. Instead they have studied socialist women, Francoist public health experts, mid-ranking soldiers and field workers as actors, and laboratories, refugee camps and even trains as sites of internationalism. At the same time, they have recognised that the histories of these actors are nationally, internationally and/or globally connected. Having adopted and explored these actors' perspectives, the articles have raised broader questions of professional, national and international identity, the legitimacy of certain internationalisms over others and the ways in which internationalism may or may not be practiced. The contributors have found some willing and some reluctant internationalists, along with some short-lived and other longer-term and far-reaching internationalisms. ${ }^{5}$

This relatively 'new' approach builds on ideas that can be considered quite 'old'. Some of its aspirations reach back to microhistory, pioneered by Carlo Ginzburg and Natalie Zemon Davis, with its focus on micro locales, individuals and everyday practices. In connecting the particular with the top-down perspective of international organisations, the exchange of ideas and the development of policies on a supranational stage, this scholarship also builds on the rich historiography of the history of science and medicine. Transnational connections, as well as the establishment and maintenance of and continuities in international scientific

Movements, 1918-1939 (Cambridge: Cambridge University Press, I995); Nitsan Chorev, The World Health Organization between North and South (Ithaca, NY: Cornell University Press, 20I2).

3 Patricia Clavin, Securing the World Economy: The Reinvention of the League of Nations, 1920-1946 (Oxford: Oxford University Press, 2013); Glenda Sluga, Internationalism in the Age of Nationalism (Philadelphia: University of Pennsylvania Press, 2013); Mark Mazower, Governing the World: The History of an Idea (New York: The Penguin Press, 20I2); Daniel Laqua, Internationalism Reconfigured: Transnational Ideas and Movements between the World Wars (London: I.B. Tauris, 20II).

${ }^{4}$ Susan Pedersen, The Guardians: The League of Nations and the Crisis of Empire (Oxford: Oxford University Press, 20I5); Tobias Rupprecht, Soviet Internationalism after Stalin: Interaction and Exchange between the USSR and Latin America During the Cold War (Cambridge: Cambridge University Press, 20I5); AnneEmanuelle Birn and Theodore M. Brown, eds., Comrades in Health: U.S. Health Internationalists, Abroad and at Home (New Brunswick, NJ: Rutgers University Press, 20I3).

5 This paper draws on the work of The Reluctant Internationalists research group at Birkbeck College, see http://www.bbk.ac.uk/ri for more details (last visited 2 Feb. 20I6). 
networks, have long been in the focus of this field, from early bioprospecting voyages, ${ }^{6}$ to Carl Linnaeus's extensive eighteenth century network, ${ }^{7}$ to the Pasteur Institutes of the twentieth century. ${ }^{8}$ Similarly, histories of gender, race and class have added nuances to the study of internationalism by directing attention to the importance of the inclusion of women, children, indigenous populations, racial minorities and disabled people not only as objects, but also as protagonists who helped to shape international policies, movements and ideas.

In terms of methodology, this historiographical shift in the history of internationalism can be best described as 'history in-between'. By weaving international politics into national contexts and individual, local experiences, we gain a sense of how governments and state organisations engaged with the policies and actions of international agencies as well as how individual experiences fed back into international policies. The individuals in this case are not only civil servants, humanitarians, local officials, doctors or nurses, but also users, recipients and 'targets' of internationalism, such as children or veterans. Since this historical analysis considers the same processes on multiple registers, it helps to break down the apparent homogeneity of international organisations and national policies without dissolving it into isolated national, local or personal experiences.

It is in connecting multiple layers and scales of analysis that this approach's strengths - and difficulties - lie. The challenges are both methodological and conceptual and depend on our choice of scale and source base. These concerns have not been exclusive to the historiography of internationalism. Questions of scale have persistently featured in conversations within global history, history of the Anthropocene and microhistory, in terms of what it is that history should do, how it should be done and with what sources. Moreover, issues of scale have centrally informed debates over the nature of agency and the significance of intellectual history. ${ }^{9}$ As a recent conversation in the American Historical Review on the subject makes clear, considering questions of scale is particularly important since it is 'profoundly methodological ... but also quite vast in its implications for how we

${ }^{6}$ Londa L. Schiebinger, Plants and Empire: Colonial Bioprospecting in the Atlantic World (Cambridge, Mass.: Harvard University Press, 2004).

7 Staffan Müller-Wille, 'Linnaeus and the Four Corners of the World', in K. Coles, R. Bauer, Z. Nunes and C. Peterson, eds., The Cultural Politics of Blood, 1500-1900 (Basingstoke: Palgrave MacMillan, 20I5), I9I-209.

8 Anne Marie Moulin, 'The Pasteur Institute's International Network: Scientific Innovations and French Tropisms', in Christophe Charle, ed., Transnational Intellectual Networks. Forms of Academic Knowledge and the Search for Cultural Identities (Frankfurt: Campus, 2004).

9 Warwick Anderson, 'Making Global Health History: The Postcolonial Worldliness of Biomedicine', Social History of Medicine, 27, 2 (20I4), 372-84; Sarah Hodges, 'The Global Menace', Social History of Medicine, 25, 3 (2012), 719-28; Bruce Mazlish, 'Big History, Little Critique', Historically Speaking, 6, 5 (2005), 43-4; David Armitage, 'What's the Big Idea?', Times Literary Supplement, 20 Sept. 20I2; G. Magnússon Sigurður and István Szijárto', What Is Microhistory?: Theory and Practice (Milton Park: Routledge, 2013). 
approach historical experience in very basic terms' ${ }^{10}$ Incorporating local experience into the history of internationalism demands consideration of how people came to interact with international organisations, as well as how they thought about, resisted or took advantage of ideas and practices of internationalism. Tracking these processes usually requires labour-intensive research in international, governmental and local archives in various countries and the mastery of several languages.

As the papers in this special issue have demonstrated, this layered analytical approach is worth the investment into multi-archival research, not just because it is intellectually rewarding but also because of its distinct contribution to the history of internationalism. Celia Donert's piece has highlighted that in order to understand how socialist internationalism operated in practice, and its significance for twentiethcentury political and social movements in both East and West, it is imperative to take into account the geopolitics of the Cold War, as well as the concerns of national governments and political organisations, and to place them alongside the personal experiences, motivation and actions of individuals on the ground. Francesca Piana's study of the ICRC and George Montandon's dealings in Siberia in the wake of the First World War has utilised a multi-level analysis that includes one individual's relationships, conflicts and opportunities both with and within the organisation. Similarly, by following Polish bacteriologists on the move, Katharina KreuderSonnen's article has uncovered the ways in which members of an international scientific community shifted between transnationalism, 'Olympic internationalism' and national allegiances. These considerations did not only pertain to the personal lives of scientists but also had direct effects on the nature of their scientific work. At the same time, these scientists navigated the rapidly changing national boundaries and sentiments around them. To what extent can they be considered agents of internationalism? The answer is: considerably so. This is exactly the community and context that Ludwik Rachjman worked in before becoming director of the League of Nations Health Organisation. Berthrand Taithe and Christine von Oertzten have also focused on local contexts - that of field-workers in humanitarian organisations in Cambodia and of women activists in interwar Germany - which nevertheless decisively shaped international organisations' agendas, policy-making and knowledge production.

The articles in this issue thus have displayed the exceptionally rich tapestry from which international history is woven. They have explored the multifaceted nature of agency and its complex relationship to ideology, identity and structure, which can only be grasped if historians continue to zoom in and out of local, national, regional and global contexts, and remain aware of the contingency of international(ist) projects as they move between the ever shifting scales of analysis.

\footnotetext{
${ }^{10}$ Sebouh David Aslanian, Joyce E. Chaplin, Ann Margaret McGrath and Kristin Mann, 'AHR Conversation How Size Matters: The Question of Scale in History', American Historical Review, II 8, 5 (20I3), I43I-72.
} 


\section{The National and International}

These shifting levels of analysis have pushed historians of internationalism to interrogate the troubled role of nationalism and national identities in the emergence of international organisations, agendas and loyalties. Kreuder-Sonnen's Polish scientists were not alone in trying to untangle the complicated relationship between nationalism and internationalism - historians have long joined their ranks in this struggle. ${ }^{11}$ For instance, Glenda Sluga's Internationalism in the Age of Nationalism argued against discussing internationalism solely in the context of utopian and unrealistic projects and ideas, and instead proposed to study nationalism and internationalism as a politically, conceptually and culturally interconnected phenomenon. ${ }^{12}$ Sluga thus deconstructed the binary between realistic nationalism and overly idealistic internationalism and studied the development of international(ist) ideas and institutions within a national framework. Her intervention highlighted that twentieth-century liberal internationalism's promoters and lynchpins rarely saw it as an idealistic opportunity to overcome national identities, but, on the contrary, considered international initiatives and projects as pragmatic and upheld by nationalism, nation-states and national institutions. In many ways Sluga followed the words, ideas and deeds of her historical actors - self-described internationalist liberal elites who took part in constructing and furthering the liberal international organisations of the twentieth century. While they have imagined the project of internationalism as a layered venture, in which internationalist political agendas rested unproblematically on nationalist loyalties, some of the articles in this volume have offered an alternative interpretation. Unlike Sluga's, these pieces have not focused on elite functionaries of liberal international institutions. Because of that, their explorations of such politically and socially diverse historical actors have made it clear that relationships between the national and the international were not necessarily straightforward. Such a shift in the scale of historical analysis has highlighted the extent to which, throughout the first half of the twentieth century, various versions of internationalism competed with one another and often sat quite uncomfortably with national affiliations.

In Alexander Watson's article on the internationalism of the Habsburg officer corps, it was primarily the absence of a strong ethnic/national identification that made it possible for pre-war officers to engage in supra-national dealings both within the Austro-Hungarian army and with other European militaries. The kind of internationalism Watson describes with reference to the pre-war generation of senior Habsburg officers thus offered an alternative to liberal nationalism - or even a challenge to it - and existed on what we might see as a parallel plane. Watson's article thus raises the question of the relationship between a-nationalism and international orientations: instead of simply assuming that international and

\footnotetext{
${ }^{11}$ See Mark Mazower, No Enchanted Palace: The End of Empire and the Ideological Origins of the United Nations (Princeton: Princeton University Press, 2009); Erez Manela, The Wilsonian Moment: Self-Determination and the International Origins of Anticolonial Nationalism (Oxford: Oxford University Press, 2007).

${ }^{12}$ Glenda Sluga, Internationalism in the Age of Nationalism (Philadelphia: University of Pennsylvania Press, 2013).
} 
transnational developments always started from firm and unquestionable national collectives and loyalties, we might ask whether meanings and goals of internationalism might be seen in a different way if national loyalties were not necessarily an essential element. Watson in fact concludes that the middle-class, liberal national loyalties of the reserve offices of the Habsburg army stymied their ability to inspire a multinational force and hindered the development of the spirit of internationalism in the AustroHungarian corps. It is, therefore, a particular version of internationalism, according to Watson, which offered the nationally indifferent senior military officers the possibility of an alternative identity. In the interwar years, as István Deák has demonstrated, those a-national Habsburg servicemen faced dire challenges and appeared rather lost and disoriented in the European maze of radical political identities and ideologies. ${ }^{13}$

Looking at other relatively recent scholarship helps us to place this in context. In her programmatic article 'Imagined Noncommunities: National Indifference as a Category of Analysis', Tara Zahra proposed national indifference as a separate historical category which could move the historiography of internationalism and transnationalism forward and resolve some of its core conundrums. ${ }^{14}$ Zahra focused particularly convincingly on disputing the idea that national indifference was a relic of pre-modern history and argued instead that important areas of national indifference emerged precisely in response to modern mass politics and nationalising movements. In borderland regions, in multinational states and in certain social groups, aggressive attempts at nationalisation and radical expressions of exclusive national loyalties in fact bred and encouraged the response of national indifference, a refusal to adopt any ethnic or national belonging as one's primary or overarching form of identification. Inter-national history seems to assume and reaffirm the existence of the national; ironically, it might actually reinstate the national as the very focus of historical research. However, Zahra's invitation to follow the transnational projects and endeavours of those who belonged to no particular national group changes our lens significantly and also probes the liberal definition of internationalism. It is in exploring such a-national discourses that Zahra sees the future of transnational and international historiography; this history from below looks at those communities of ordinary people who professed national indifference and opposed the totalising nationalising campaigns of the twentieth century. The history of internationalism would thus benefit enormously from a 'bottom-up' approach. East-central Europe might then serve as a particularly useful and enlightening site of internationalism and transnationalism, rather than being relegated to the margins of the thriving, Western-focused field of the history of internationalism.

All this also raises the question of the precise definition of internationalism. If we move away from standard liberal conceptualisations, then what constitutes an internationalist or an international project? For Watson, those were all those officers

\footnotetext{
${ }^{13}$ István Deák, Beyond Nationalism: A Social and Political History of the Habsburg Officer Corps, 1848-1918 (Oxford: Oxford University Press, I990).

${ }^{14}$ Tara Zahra, 'Imagined Non-Communities: National Indifference as a Category of Analysis', Slavic Review, 69, I (2010), 93-II9.
} 
who had no primary national affiliation, inspired multinational devotion of soldiers in their military units and also looked across the border to learn from other armies' experiences and innovations. But is an internationalist someone who simply has an awareness of the world outside his or her own nation-state, or is there a more demanding requirement, a yardstick against which to measure one's cross-national commitments? In a similar vein, can we apply the concept of internationalism to the study of relations between different national or ethnic groups within a multinational empire, or is 'a-nationalism' or 'national indifference' indeed a more appropriate term in that context? Finally, some historians have argued that the concept of 'transnationalism' can serve better to recover those developments from below, and to capture the experiences and manifestations of national indifference. This is an intriguing and potentially fruitful idea, but more conceptual and practical work remains to be done to clarify what exactly the difference might be between internationalism and transnationalism as analytical lenses.

\section{Alternative Internationalisms}

The articles in this special issue have cast a variety of hitherto neglected historical actors as likely or unlikely agents of internationalism. As discussed above, these agents' visions of international engagements, collaborations and goals were strikingly varied and often clashed with liberal conceptions of internationalism. Some of these people were indeed reluctant (or better: accidental) internationalists, whose intellectual trajectories highlighted the extreme ideological diversity of transnational projects. As the contributions of Donert, Brydan and Watson have suggested, more than one kind of internationalism was in play in Europe in the twentieth century, and many of these blueprints for international collaboration were not benevolent or inspired by humanitarian ideas. Yet socialist, communist and National Socialist internationalism have all had a marginal place in the 'new international history'. ${ }^{15}$ Recapturing the idealism and dynamism of those alternative internationalisms was one of the aims of the essays collected here, adding to a rapidly growing body of new scholarship. The exploration of alternative internationalist networks can only be achieved if the history of internationalism is geographically de-centred: if it moves away from the exclusively Western focus to include those regions in Eastern, Southern and Central Europe which have so far largely been ignored. That is exactly what this volume has aimed to achieve.

As Mark Mazower has convincingly argued, for much of the twentieth century, the victory of the ideas of liberal democracy and liberal internationalism was by no means certain. ${ }^{16}$ The liberal international order was successfully challenged from both the far right and the far left, and its prospects looked particularly bleak in the late I920s

\footnotetext{
${ }^{15}$ Natasha Wheatley, 'The Compass of International History: Eric Hobsbawm and After', Journal of Modern European History, II, 4 (20I3), 427. An international dimension to 'national indifference' has been suggested in the section above.

${ }^{16}$ Mark Mazower, Dark Continent: Europe's Twentieth Century (New York: Vintage, 200o).
} 
and throughout the I930s, when it seemed that communism in the Soviet Union and fascism/National Socialism in Central and Southern Europe had discovered more efficient and functional formulae for organising the state, the economy and the masses. Most of the articles in this issue focus on the I93Os, this crucial and troubling decade of feverish international activity and, in doing so, expand our understanding of the institutional and ideological framework of pre-Second World War internationalism. As these articles demonstrate, attempts to strengthen the liberal, international order were marred by nagging doubts about the viability of liberal solutions to pressing political and social problems. Europe seemed threatened, left to languish in post-war ruins by inefficient and weak parliaments and powerless international organisations. Non-liberal approaches to reconstruction and renewal gained in status, and in the I930s reformism gave way to radicalism. This collection has explored different ways in which Europeans imagined the redemption of Europe and the globe throughout the twentieth century and how such radically different conceptions of international links and setups affected subsequent and contemporary understandings of the international order.

In exploring these alternative internationalisms, it becomes clear that debates have been strongly shaped by Cold War narratives that still await critical examination. Our understanding of socialist and communist internationalism, in particular, has been stamped by Cold War binaries and biases. Cold War era scholarship on communist internationalism focused mainly on understanding the mechanisms by which communism spread, an emphasis paired to the aim of subverting those mechanisms through a militarised US strategy of containment. Scholars sought answers to the critical question of how communism spread in a narrow field, researching military force, coercion and political conspiracy. ${ }^{17}$ During the Cold War, the genuine grassroots appeal of international communism was treated with enormous scepticism in the West, as well as in Western scholarship. This scepticism is illustrated by the American officials in Donert's paper, who saw women as irrationally vulnerable to the emotional appeal of communism rather than taking their political commitments seriously, although the trials the women faced suggest that they perceived the threat from the communists to be stronger than they let on.

Such a tendency to downplay legitimate commitment to communism is particularly strongly expressed in both Cold War era and more recent studies of communism in Eastern Europe. Historians have rarely discussed indigenous communist and socialist movements that existed in Eastern Europe in the years of the Second International, in the interwar years or during the Cold War, nor their relations to a broader, international sphere. During the Cold War, Eastern Europe served instead as the paradigmatic example of communism forged by military intervention, forced on unwilling and unenthusiastic participants. This thesis was seemingly proven

\footnotetext{
${ }^{17}$ Yet as recent scholarship has demonstrated, the spread of socialism was often beyond the control of Soviet officials, as illustrated by the example of the Cuban revolution and aftermath, on which see especially Vladislav Zubok, A Failed Empire: The Soviet Union in the Cold War from Stalin to Gorbachev (Chapel Hill: The University of North Carolina Press, 2009).
} 
by the flashpoint events of the Hungarian uprising and the crushing of the Prague Spring. ${ }^{18}$ The Cold War narrative of 'Sovietisation with the stick' remains deeply embedded in our scholarly understanding of communist internationalism, particularly in Eastern Europe.

Indeed, this Cold War-era framework of assuming the illegitimacy of socialism or communism in Eastern Europe was even projected back in time. As if to underline the political irrelevance of pre-First World War socialism, scholarship on the Second International practically halted during the Cold War, and the topic remains understudied. ${ }^{19}$ Continuities between the Second International and the Third (Comintern) continue to be downplayed. Most scholarship dedicated to communist internationalism in the West, socialist internationalism in the East or the Second International does not cross over the First World War divide, taking the Great War as either an ending or starting point. ${ }^{20}$

Yet the critical examination of this literature has now begun. ${ }^{21}$ An emerging body of scholarship has offered an alternative to this narrative of illegitimacy, taking Eastern Europe as its starting point. This work focuses on the ways in which socialist internationalism (as it is called in this literature, referring to networks within the Soviet sphere as 'socialist' rather than 'communist') actually expanded the horizons of many actors, particularly after the death of Stalin in I953. 'Building socialism' introduced new forms of social and cultural mobility. As Elidor Mëhilli has outlined in a series of articles and chapters, the socialist experiment opened up a world of opportunity to experts and workers in peripheral states such as Albania to not only work to develop their own homeland but to also build socialism abroad. ${ }^{22}$ New

${ }^{18}$ Anne Applebaum, Iron Curtain: The Crushing of Eastern Europe 1944-56 (New York: The Penguin Press, 20I2); Odd Arne Westad, The Global Cold War: Third World Interventions and the Making of Our Times (Cambridge: Cambridge University Press, 2007). This is not to dismiss the significance of resistance to Soviet influence in these countries or to trivialise the cause of dissidents, or to deny the violence and coercion that the Soviets employed.

${ }^{19}$ The definitive histories of the Second International remain James Joll, The Second International: 18891914 (London: Routledge, I974); and Georges Haupt, Socialism and the Great War: The Collapse of the Second International (Oxford: Clarendon Press, I972). More recently, interest in the theme has increased. See Timothy Snyder, Nationalism, Marxism, and Modern Central Europe: A Biography of Kazimierz KellesKrauz, 1872-1905 (Cambridge, MA: Harvard University Press, 1997); Marci Shore, Caviar and Ashes: A Warsaw Generation's Life and Death in Marxism, 1918-1968 (New Haven: Yale University Press, 2006); and Kevin Callahan, Demonstration Culture: European Socialism and the Second International, 1889-1914 (Kibworth Beauchap: Troubadour, 20I0).

${ }^{20}$ See, for example, Silvio Pons, The Global Revolution: A History of International Communism 1917-1991 (Oxford: Oxford University Press, 20I4).

${ }^{21}$ Bradley F. Abrams, The Struggle for the Soul of the Nation: Czech Culture and the Rise of Communism (Lanham, MD: Rowman \& Littlefield, 2005); Mark Pittaway, The Workers' State: Industrial Labor and the Making of Socialist Hungary, 1944-1958 (Pittsburgh: University of Pittsburgh Press, 20I2); Jan Palmowski, Inventing a Socialist Nation: Heimat and the Politics of Everyday Life in the GDR, 1945-9o (Cambridge: Cambridge University Press, 2013).

${ }^{22}$ Elidor Mëhilli, 'The Socialist Design: Urban Dilemmas in Postwar Europe and the Soviet Union', Kritika: Explorations in Russian and Eurasian History, I3, 3 (20I2): 635-65; Elidor Mëhilli, 'Socialist Encounters: Albania and the Transnational Eastern Bloc in the I950s', in Patryk Babiracki and Kenyon Zimmer, eds., Cold War Crossings: International Travel and Exchange across the Soviet Bloc, 1940s-1960s (College Station: Texas A \& M University Press, 2014), I07-33. See also the special issue by Lukasz 
scholarship has highlighted the impact that studying abroad in the Soviet Union had in developing countries and Eastern Europe. ${ }^{23}$ And, for many workers, socialism brought the first opportunities to travel abroad as tourists, primarily within what Rachel Applebaum calls the 'socialist world', to such destinations as the Black Sea, Moscow and Leningrad, but also beyond it. ${ }^{24}$ On a micro-historical level, shopping trips across borders acted as a stabilising factor within the Eastern Bloc, as deficit goods could at times be found abroad. ${ }^{25}$ The search for education, professional advancement, prosperity, national independence and social justice were among the many factors that motivated Eastern Europeans to take part in building socialism across the Soviet sphere. But there were also many mundane, everyday concerns and cultural practices that bound the Bloc together. ${ }^{26}$

Ideology and radical politics were not always a primary motivating force for linking into international networks in the socialist world. But at the same time, ideology mattered; the Soviet Bloc was also an ideological project. ${ }^{27}$ And, indeed, mobility exposed the different levels of commitment to the socialist ideological project within the Eastern Bloc, with Soviets often surprising visitors with their lack of knowledge of or commitment to Marxism-Leninism. ${ }^{28}$ The legitimacy of the socialist world not only rested on military intervention and coercion, but was also forged through

Stanek and Tom Avermaete, eds., 'Cold War Transfer: Architecture and Planning from Socialist Countries in the "Third World", Journal of Architecture, I7, 3 (2012).

${ }^{23}$ Julie Hessler, 'Death of an African Student in Moscow: Race, Politics, and the Cold War', Cahiers du Monde Russe, 47, I-2 (2006), 33-63; Maxim Matusevich, 'Probing the Limits of Internationalism: African Students Confront Soviet Ritual', Anthropology of East Europe Review, 27, 2 (2009), I9-39; Masha Kirasirova, 'Sons of Muslims in Moscow: Soviet Central Asian Mediators to the Foreign East, I955-I962', Ab Imperio, 4 (20II), I06-32; Benjamin Tromly, 'Brother or Other? East European Students in Soviet Higher Education Establishments, I948-I956', European History Quarterly, 44, I (20I4), 80I02; Rachel Applebaum, 'The Friendship Project: Socialist Internationalism in the Soviet Union and Czechoslovakia in the I950s and I960s', Slavic Review, 74, 3 (Fall 2015), 484-507.

${ }^{24}$ On tourism, see Diane P. Koenker and Anne Gorsuch, eds., Turizm: The Russian and East European Tourist under Capitalism and Socialism (Ithaca: Cornell University Press, 2006); Anne Gorsuch, All This is Your World: Soviet Tourism at Home and Abroad After Stalin (Oxford: Oxford University Press, 20II); Diane Koenker, Club Red: Vacation Travel and the Soviet Dream (Ithaca: Cornell Unviersity Press, 2013).

${ }^{25}$ Cristina Petrescu, 'Entrepreneurial Tourism in Romania: A System-Stabilizing Factor?' in Włodzimierz Borodziej, Jerzy Kochanowski and Joachim von Puttkamer, eds., Schleichwege: Inoffizielle Begegnungen sozialistischer Staatsbürger zwischen 1956 und 1989 (Köln: Böhlau Verlag, 20Io), II5. See also Paulina Bren and Mary Neuburger, eds., Communism Unwrapped: Consumption in Cold War Eastern Europe (Oxford: Oxford University Press, 20I2), especially the contribution of Mark Keck-Szajbel, 'Shop Around the Bloc: Trader Tourism and Its Discontents on the East German-Polish Border', in ibid., 374-92. See also the special issue devoted to consumer tourism in the socialist world, Cultural Studies, I6, I, (2002).

${ }^{26}$ Rachel Applebaum, 'The Friendship Project'.

${ }^{27}$ Jan Behrends, Die erfundene Freundschaft: Propaganda für die Sowjetunion in Polen und der DDR 1944-1957 (Köln: Böhlau Verlag, 2005).

${ }^{28}$ Young East Germans who attended the I968 World Youth Festival were dismayed by the lack of knowledge of and enthusiasm for Marxist ideology among Soviet delegates, and came to the conclusion that they were the better communists. See Nicholas Rutter, 'Look Left, Drive Right: Internationalisms at the I968 World Youth Festival', in Anne E. Gorsuch and Diane P. Koenker, eds., The Socialist Sixties: Crossing Borders in the Second World (Bloomington: Indiana University Press, 20I2), I93-2I2; Nicholas Rutter, 'The Western Wall: The Iron Curtain Recast in Midsummer I95I', in Babiracki and Zimmer, Cold War Crossings, 78-106. 
complex exchanges of goods, ideas and people, as well as through projects of social and cultural integration. ${ }^{29}$ Yet we still know remarkably little about these social, cultural and economic contacts and collaborations through which socialist Eastern Europe was forged.

Perhaps, too, the binary of reformist Western socialist internationalism and revolutionary Eastern communist internationalism has been overstated: certainly the communist organisations went through periods of reformism (during the years of the United and Popular Fronts, for example), and Western socialist internationalists occasionally engaged in direct action. A rich, new body of work on socialist internationalism in Western Europe points to the many ambiguities in the relationship of the socialists to nationalism and colonialism, and, indeed, Marxism. ${ }^{30}$

The spread of National Socialism beyond the borders of Germany has also attracted notable historical attention, but this research has largely been focused on national case studies, or examinations of particular fascistic and right-wing movements and their leaders. ${ }^{31}$ But the Third Reich inspired alternative - and elaborate - visions of European and global international order, and historians have begun struggling with interpreting the meaning and limitations of such 'Nazi dreams of Europe', colonialism and global leadership.

While the view that the Third Reich's European rhetoric served as a mere (and crude) propaganda tool has merit (particularly with regard to the Nazi occupation of the Soviet Union and Eastern Europe), several historians have argued convincingly that the idea of a 'New Europe' should not be dismissed so easily. German interventions in the theory of internationalism and international organisations deeply challenged the liberal postulates, and diverse voices within the Nazi movement offered multiple solutions and sought to engage various allies in both Eastern and Western Europe (as well as outside Europe). The Nazi discourse on European unity and solidarity proclaimed an 'epoch of the community of the free peoples of Europe', that would create an atmosphere of 'comradeship' of all European nations, finally freed from the liberal-capitalist plutocratic system that abused and de-legitimised

\footnotetext{
${ }^{29}$ Oscar Sanchez-Sibony, Red Globalization: The Political Economy of the Soviet Cold War from Stalin to Khrushchev (Cambridge: Cambridge University Press, 20I4); Nick Baron, 'World Revolution and Cartography', in Mark Monmonier, ed., The History of Cartography, vol. 6: Cartography in the Twentieth Century (Chicago: University of Chicago Press, 2015), I766-70; Maxim Matusevich, No Easy Row for a Russian Hoe: Ideology and Pragmatism in Nigerian-Soviet Relations, 1960-1991 (Trenton, NJ: Africa World Press, 2003); Austin T. Jersild, The Sino-Soviet Alliance: An International History (Chapel Hill, NC: University of North Carolina Press, 20I4); Alastair Kocho-Wiliams, Russian and Soviet Diplomacy, 190039 (Basingstoke: Palgrave Macmillan, 20I2); and Alastair Kocho-Wiliams, Russia's International Relations in the Twentieth Century (London: Taylor and Francis, 20I2). See also the review by Jan Hennings, 'World Revolution and International Diplomacy, I900-39', in Kritika: Explorations in Russian and Eurasian History, I6, I (2015), 204-IO.

${ }^{30}$ See, for example, Daniel Laqua, 'Democratic Politics and the League of Nations: The Labour and Socialist International as a Protagonist of Interwar Internationalism', Contemporary European History, 24, 2 (2015), I75-92.

${ }^{31}$ For a notable exception, see Mark Mazower, Hitler's Empire: How the Nazis Ruled Europe (New York: The Penguin Press, 2009); for fascist Italy's project of building the new order in the Mediterranean, see Davide Rodogno, Fascism's European Empire (Cambridge: Cambridge University Press, 2006).
} 
concepts such as self-determination and democracy. This project, of course, clashed with, and was ultimately made impossible due to, the very core of Nazi racial ideology and violence. Still, there were elaborate attempts on the part of some Nazi ideologues and policy makers to be 'softer on the Untermenschen', to demonstrate to the local populations that they were not merely 'colonial property' and that they could be treated as organic parts of the 'European great region'. These attempts at developing an internationalist discourse mainly aimed to prevent the alienation of subject peoples and, most notably, of the pro-Nazi soldiers coming from the eastern territories. ${ }^{32}$ The Nazis also nurtured a consistent (if crude) anti-Western and anti-Orientalist rhetoric and repeatedly tried to enlist Muslims and the Islamic world in their own crusade against Jews, Bolshevism and Western liberalism. ${ }^{33}$

And while the literature on the Third Reich's elaborations of Axis internationalism has made some notable forays, ${ }^{34}$ we still know very little about how various occupied states responded to this new concept of Europe. ${ }^{35}$ In particular, it still remains largely unclear how the occupied territories in Eastern Europe understood their own place in the 'New Europe' and how they resolved the major contradiction between the Nazi talk of Europeanisation and the extreme brutality of their occupation policies. Holly Case showed that Hitler's eastern allies - Romania and Hungary - treated Germany as the creator of a 'New Europe' and addressed it to further their own national aims as they did the League of Nations in the interwar years. ${ }^{36}$ This is an under-researched yet growing historical field: as Patrick Bernhard has recently shown, the exploration of the ideological links between Mussolini's colonial project in Africa and Nazi designs for Eastern Europe can have far-reaching effects on our understanding of fascism, National Socialism and the Second World War. ${ }^{37}$ But beyond the Third Reich's allies, was Germany's propaganda regarding European camaraderie taken seriously by any of the local actors in Second World War Europe? What did the Third Reich's dubious internationalism mean across the rest of the continent, and did it have anything to offer to the intelligentsia as well as the population at large in the occupied, allied or neutral territories? Was the 'New Europe' under the banners of National Socialism a

\footnotetext{
${ }^{32}$ Robert Edwin Herzstein, When Nazi Dreams Come True: The Third Reich's Internal Struggle over the Future of Europe after a German Victory (London: Abacus, I982).

${ }^{33}$ David Motadel, Islam and Nazi Germany's War (Cambridge: Harvard University Press, 20I4).

${ }^{34}$ Michael Salewski, 'National Socialist Ideas on Europe', in Walter Lipgens, ed., Documents on the History of European Integration, Volume 1, Continental Plans for European Union 1939-1945 (Berlin: Walter de Gruyter, 1984), 37-I78; Elizabeth Harvey, 'International Networks and Cross-Border Cooperation: National Socialist Women and the Vision of a "New Order" in Europe', Politics, Religion and Ideology, I3, 2 (20I2), I4I-58; Benjamin George Martin, "“European Literature” in the Nazi New Order: The Cultural Politics of the European Writer's Union, I942-3', Journal of Contemporary History, 48, 3 (2013), 486-508.

${ }^{35}$ See Martin Gutmann, 'Debunking the Myth of the Volunteers: Transnational Volunteering in the Nazi Waffen-SS Officer Corps during the Second World War', Contemporary European History, 22, 4 (2013), 585-607.

${ }^{36}$ Holly Case, Between States: The Transylvanian Question and the European Idea during WWII (Ithaca, NY: Cornell University Press, 2009).

${ }^{37}$ Patrick Bernhard, 'Hitler's Africa in the East: Italian Colonialism as a Model for German Planning in Eastern Europe', Journal of Contemporary History, 5I, I (20I6), 6I-90.
} 
lived experience anywhere in Europe, and did it offer opportunities to non-Germans which had been frustrated in the context of the liberal order? David Brydan's article on how this project of the 'New Europe' was understood and practiced on the margins of Europe - in Spain - partly fills this historiographical lacuna. Moreover, it emphasises the continuity between liberal and non-liberal internationalist networks and demonstrates how they could easily overlap and employ some of the same agents and political agendas. In a recent article, David Kuchenbuch has demonstrated that transnational transfers of knowledge could flourish between architects and urban planners in Nazi Germany and social-democratic Sweden, despite their seemingly insurmountable ideological differences. ${ }^{38}$

The crumbling of the liberal world order in the I930s was perhaps best manifested in the failure of the state to fulfil its core promises. In that context, those alternative networks of internationalism in operation in the I930s and I94Os centred on promoting a different model of the state. As David Brydan shows, what motivated Spanish health experts to avidly join the German-centred networks of medical professionals was not necessarily ideological radicalism but rather a search for a more efficient state model of healthcare and welfare. In that sense, mid-twentieth-century internationalisms led to a paradoxical situation in that they encouraged the formation of transnational networks which sought to find out ways to strengthen the social and political institutions of the (nation-)state. This was the kind of internationalism that encouraged nations to be ever more exclusive and nationalistic. ${ }^{39}$

Writing socialist and national socialist internationalism into international history is part of a broader historiographical shift. This scholarship de-centres the traditional geography of internationalism. It takes the view not only from Geneva, Paris or London, but also from Moscow and Berlin and, further, capitals such as Madrid and Bucharest. Moreover, it explores the perspectives of actors not only from the Western world, but also from Eastern and Southern Europe, and Asia. At the same time, it dispenses with the idea that either 'internationalism' or 'transnationalism' was exclusively about surpassing narrow national, ethnic or racial loyalties in order to deepen the friendship among peoples. Instead, it shows that internationalist endeavours often could sit uncomfortably well with imperialist, violent and chauvinistic political or cultural projects. Finally, rather than solely exploring the perspectives of internationally minded elites or policy makers, historians of internationalism have begun to make fruitful and original contributions by focusing on how such transnational schemes and border crossings affected everyday lives and lived experiences, and how they shaped particular local communities in different regions of the world.

\footnotetext{
${ }^{38}$ David Kuchenbuch, 'Architecture and Urban Planning as Social Engineering: Selective Transfers between Germany and Sweden in the I930s and I940s', Journal of Contemporary History, 5I, I (20I6), 22-39.

${ }^{39}$ A similar argument has been made by Alan Milward for Western European states, for example, Alan Milward, The Reconstruction of Western Europe, 1945-1951 (New York, Routledge, 2003); and Alan Milward, The European Rescue of the Nation-State (Hove: Psychology Press, 2000).
} 